\title{
Nuclear DNA content and chromosome number of Krameria cistoidea Hook. \& Arn. (Krameriaceae)
}

\section{Contenido de ADN nuclear y número cromosómico de Krameria cistoidea Hook. \& Arn. (Krameriaceae)}

\author{
Claudio Palma-Rojas ${ }^{1 *}$, Pedro Jara-Seguel ${ }^{2}$, Marjorie Garcia ${ }^{1} \&$ Elisabeth von Brand ${ }^{3}$ \\ ${ }^{1}$ Departamento de Biología, Facultad de Ciencias, Universidad de La Serena, Casilla 599, La Serena, Chile. \\ ${ }^{2}$ Escuela de Ciencias Ambientales y Núcleo de Estudios Ambientales, Facultad de Recursos Naturales, Universidad Católica de \\ Temuco, Casilla 15-D, Temuco, Chile. \\ ${ }^{3}$ Departamento de Biología Marina, Facultad de Ciencias del Mar, Universidad Católica del Norte, Casilla 117, Coquimbo, \\ Chile. \\ *cpalma@userena.cl
}

\begin{abstract}
RESUMEN
Krameria cistoidea Hook. \& Arn. tiene un valor 2C de 18,64 \pm 1,09 pg con un coeficiente de variación de 5,8\%. El número cromosómico $2 \mathrm{n}=12$ descrito para otras seis especies de Krameria está también presente en $K$. cistoidea. Estos datos citológicos de $K$. cistoidea son discutidos en relación a antecedentes disponibles para otras Angiospermas, así como para tres géneros de la familia taxonómicamente relacionada Zygophyllaceae.
\end{abstract}

Krameria cistoidea Hook. \& Arn. (Krameriaceae) is a species endemic to Chile that inhabits coastal and preandean slopes (Squeo et al. 2001), with a center of distribution located between the rivers Huasco $\left(28^{\circ} \mathrm{S}\right)$ and Limari $\left(30^{\circ} \mathrm{S}\right)$ in the semiarid zone. Along its geographical range $K$. cistoidea shares the habitat with its sister species K. lappacea (Dombey) Burdef \& Simpson. At present, almost 16 Krameria species have been described across the Americas, but only two species are present in Chile. The taxonomic classification of Krameria has been principally based upon morphology, anatomy, pollen ultra-structure, wood anatomy and DNA sequences (Heusser 1971, Robertson 1973, Simpson \& Skvarla 1981, Soltis et al. 2000, Simpson et al. 2004, Carlquist 2005). Nevertheless, since its description by Loefling in 1758, the genus Krameria has presented a problem to taxonomists as to its placement within the dicotyledons (Robertson 1973, Simpson \& Skvarla 1981). Currently, Krameria is classified within the Zygophyllales order together with other genera belonging to the family Zygophyllaceae (Soltis et al. 2000, Simpson et al. 2004). Cytological studies carried out previously for five Krameria species show a haploid chromosome number $\mathrm{n}=6$ (Turner 1958, Lewis et al. 1962). Nevertheless, cytological data such as nuclear DNA content (or 2C-values) have not been estimated for Krameria species, nor the chromosome number has been reported previously for the taxa that inhabits Chile. On this respect, $2 \mathrm{C}$-values and/or 2 n numbers have been previously described for genera belonging to the related family Zygophyllaceae (e.g. Larrea, Bulnesia, Tribulus). These genera show cytological characters that differ to Krameria species described so far, with diploid species $(2 \mathrm{n}=26)$, tetraploids $(2 \mathrm{n}=52)$, hexaploids $(2 \mathrm{n}=$ $78)$ and octoploids $(2 \mathrm{n}=104)$, and all having low $2 \mathrm{C}$-values (ranging between 0.7 and 4.5 pg) (Poggio \& Hunziker 1986, Poggio et al. 1989, Laport et al. 2012).

The goal of this work is to describe the $2 \mathrm{C}$-value and the chromosome number of $K$. cistoidea, thus increasing the cytological information available for the genus. These cytological data, although partial, may contribute to improve the understanding on cyto-evolutionary patterns within the family Krameriaceae, which could also be important characters to corroborate its current classification within the order Zygophyllales.

Plants of Krameria cistoidea were collected from a naturally growing population in Chile, Coquimbo Region, Provincia de Elqui, Cuesta El Churque to $35 \mathrm{~km}$ south of Vicuña by route D-445, 800m $\left(30^{\circ} 02^{\prime} \mathrm{S}\right.$; 7052'W), 25III-2010. G. Arancio, GA3686. The voucher specimens were deposited at the Herbarium of the Universidad de La Serena, La Serena - Chile. To count chromosomes, roots of germinated seeds were pre-treated with 8-Hydroxiquinoline $2 \mathrm{mM}$ at $7{ }^{\circ} \mathrm{C}$ for $3 \mathrm{~h}$, fixed in ethanol-glacial acetic acid $(3: 1 \mathrm{v} / \mathrm{v})$ at $4^{\circ} \mathrm{C}$ for $24 \mathrm{~h}$, and stored in ethanol $70 \%(\mathrm{v} / \mathrm{v})$ at $4^{\circ} \mathrm{C}$ until required. The roots were stained with the Feulgen reaction and chromosome preparations were made by squashing the root tips. The chromosome count was made on 
ten metaphases obtained from ten individuals. To estimate the nuclear DNA content $(2 \mathrm{C}$-values, which is defined as the total amount of DNA contained within the diploid chromosome set of the cell) Feulgen image densitometry of root tip cells were analyzed, using the software Image ProPlus 4.0 (Copyright (C) by Media Cybernetic, 1993-1998). The cells of $K$. cistoidea were squashed on slides, air-dried, fixed in methanol-glacial acetic acid $(3: 1, \mathrm{v} / \mathrm{v})$ at $4^{\circ} \mathrm{C}$ for $24 \mathrm{~h}$ and stained with the Feulgen reaction (hydrolysis with $5 \mathrm{~N} \mathrm{HCl}$ for $60 \mathrm{~min}$ at room temperature, staining with Schiff's reagent for $60 \mathrm{~min}$, followed by three washes of 5 min each using sulphurous water). The software captures black and white images from the microscope Nikon Eclipse 400 connected to CCD COHU camera, and analyzes the different visible structures on the images. Nuclear optical density (OD) is calculated by the software according to the formula OD $=\log _{10}(1 / \mathrm{T})=-\log _{10} \mathrm{~T}$, where $\mathrm{T}=$ intensity of transmitted light/intensity of incident light. From this estimation, the computer integrates the values of OD obtained for each one of the pixels and calculates the integrated optical density (IOD $=\Sigma \mathrm{OD})$. For $K$. cistoidea IOD values of 50 early prophase nuclei and 50 late telophase nuclei of root tip cells were determined by the software. The IOD values were converted to absolute mass of DNA by simultaneous comparison with nuclei of root tip cells of Allium cepa $(2 \mathrm{C}=33.5 \mathrm{pg}$, Bennett \& Leitch 2005). The root tip cells of the standard were included in the same staining runs and IOD estimations with the cells of $K$. cistoidea. The 2C-value was determined using the equation $\mathrm{CVu}=$ $\mathrm{CVs} \times$ (IODu/IODs). In the equation $\mathrm{CVu}=2 \mathrm{C}$-value of $K$. cistoidea, $\mathrm{CVs}=2 \mathrm{C}$ value of standard; IODu = average IOD of $K$. cistoidea IODs = average IOD of standard.

Krameria cistoidea showed a 2C-value of $18.64 \pm 1.09$ pg with a coefficient of variation of $5.8 \%$ (Table 1 ). The $2 \mathrm{C}$-value of $K$. cistoidea can be classified as intermediate according to the ranges described for Angiosperms (intermediate range varies between 7.0 and $28 \mathrm{pg}$ ). Other Angiosperms may show higher $2 \mathrm{C}$-values $(\geq 28 \mathrm{pg}$ ) or lower $2 \mathrm{C}$-values $(\leq 7.0 \mathrm{pg})$ according to the group, being recognized other four ranges (Leitch et al. 2005). Besides, $K$. cistoidea had a mean $2 \mathrm{C}$-value higher than the mean of $6.3 \mathrm{pg}$ described for Angiosperms.

The chromosome number $2 \mathrm{n}=12$ of $K$. cistoidea (Fig. 1) was similar to the previously described for other six species of the genus (Turner 1958). According to qualitative observations made here, the chromosomes of $K$. cistoidea have a length between $8 \mu \mathrm{m}$ and $10 \mu \mathrm{m}$. Nevertheless, quantitative studies on karyotype morphology have to be made in populations of $K$. cistoidea to corroborate these observations.

Within the order Zygophyllales the family Zygophyllaceae is the most studied on the basis of $2 \mathrm{C}$-values and ploidy levels. Thus, some species of the genus Larrea and the genus Bulnesia show 2C-values lower then $K$. cistoidea. In the genus Larrea diploid species $(2 \mathrm{n}=$ 26) show mean $2 \mathrm{C}$-values between 0.9 to $1.5 \mathrm{pg}$, whereas the tetraploid $(2 \mathrm{n}=52)$ and hexaploid $(2 \mathrm{n}=78)$ species show 2C-values between 1.8 to $3.1 \mathrm{pg}$ (Poggio et al. 1989, Laport et al. 2012). In the case of the genus Bulnesia, a wide variation in $2 \mathrm{C}$-values was observed among diploid species $(2 \mathrm{n}=26)$ with a range between $0.8 \mathrm{pg}$ and $4.5 \mathrm{pg}$. Besides, the chromosome size decreases in higher ploidy levels where octoploid species $(2 \mathrm{n}=104)$ have $2 \mathrm{C}$-values near to 0.5 pg (Poggio \& Hunziker 1986). These differences in 2C-values among $K$. cistoidea and Larrea-Bulnesia may be explained by variations in chromosome size, as it was previously described to compare species within the genus Bulnesia (Poggio \& Hunziker 1986). Another genus cytologically studied within the Zygophyllaceae is Tribulus. This genus has a basic chromosome number $\mathrm{x}=6$ similar to Krameria, but only tetraploid and hexaploid species have been described so far, with 2 n numbers of 24 and 36, respectively (Hilu 1981). At present, no data are available on 2C-values for Tribulus. Finally, all these observations described here show inconsistencies when compared 2C-values, $2 \mathrm{n}$ numbers, and ploidy levels among Krameria (Krameriaceae), Larrea and Bulnesia (both belonging to Zygophyllaceae), which could question its classification within Zygophyllales. All these information suggests that the $2 \mathrm{C}$-value and the chromosome number could be robust characters to analyze phylogenetically the controversial taxonomic classification of the family Krameriaceae within the Zygophyllales order. This situation was previously evidenced on the basis of cytogenetic, molecular and morphological characters (Turner 1958, Soltis et al. 2000, Simpson et al. 2004).

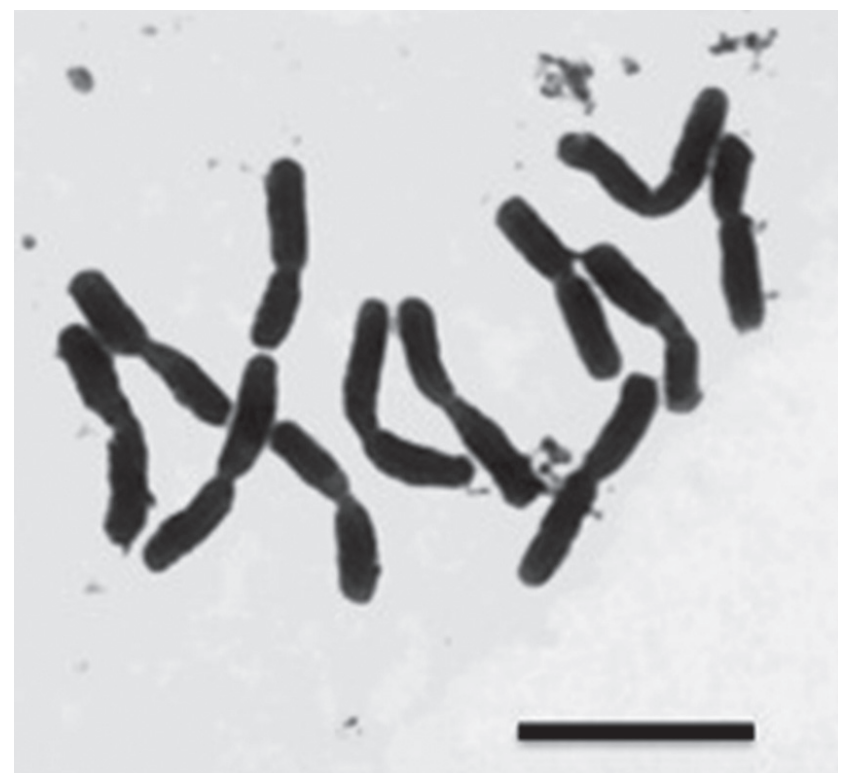

FIGURE 1. Feulgen stained metaphase of Krameria cistoidea, $2 \mathrm{n}=$ 12. $\mathrm{Bar}=10 \mu \mathrm{m}$. / Metafase de Krameria cistoidea, teñida con la Reacción de Feulgen, $2 \mathrm{n}=12$. Barra $=10 \mu \mathrm{m}$. 
TABLE 1. IOD values in arbitrary units (au) and nuclear DNA content in picograms (pg) of 50 late telophase (2C) and 50 early prophase (4C) nuclei of the standard Allium cepa and of the sample Krameria cistoidea. LT, late telophase; EP, early prophase; IOD, integrate optical density in arbitrary units. / Valores de IOD en unidades arbitrarias (au) y contenido de ADN nuclear en picogramos (pg) de 50 núcleos en telofase tardía (2C) y 50 núcleos en profase temprana (4C) del estándar Allium cepa y de la muestra Krameria cistoidea. LT, telofase tardía, EP, profase temprana; IOD, densidad óptica integrada en unidades arbitrarias.

\begin{tabular}{|c|c|c|c|c|c|}
\hline Species & $\begin{array}{l}\text { IOD LT (au) } \\
(\mathrm{MEAN} \pm \mathrm{SD})\end{array}$ & $\begin{array}{l}\text { 2C DNA CONTENT (pg) } \\
\text { LT }(\text { MEAN } \pm \mathrm{SD})\end{array}$ & $\begin{array}{l}\text { IOD EP (au) } \\
(\mathrm{MEAN} \pm \mathrm{SD})\end{array}$ & $\begin{array}{l}\text { 4C DNA CONTENT (pg) } \\
\text { EP }(\text { MEAN } \pm \text { SD })\end{array}$ & $2 n$ \\
\hline A. cepa L. & $26320 \pm 1099$ & $33.5 \pm 1.40$ & $53390 \pm 2451$ & $67.5 \pm 3.12$ & 16 \\
\hline K. cistoidea Hook. \& Arn. & $14643 \pm 794$ & $18.64 \pm 1.09$ & $29121 \pm 1268$ & $37.06 \pm 1.61$ & 12 \\
\hline
\end{tabular}

\section{REFERENCES}

Bennett, M., Leitch, I. 2005. Nuclear DNA amounts in Angiosperms: Progress, problems and prospects. Annals of Botany 95: 45-90.

Carlquist, S. 2005. Wood anatomy of Krameriaceae with comparisons with Zygophyllaceae: Phylesis, ecology and systematics. Botanical Journal of the Linnean Society 149: 257-270.

Heusser, C. 1971. Pollen and spores of Chile. Arizona Press, Tucson. 167 pp.

HiLu, K. 1981. Cytotaxonomical studies in Tribulus terrestris and T. alatus (Zygophyllaceae). Nordic Journal of Botany 1: 531-534.

Laport, R., Minckley, R., Ramsey, J. 2012. Phylogeny and cytogeography of the North American Creosote Bush (Larrea tridentata, Zygophyllaceae). Systematic Botany 37(1): 1-12.

Leitch, I., Soltis, D., Soltis, P., Bennett, M. 2005. Evolution of DNA amounts across land plants (Enbryophyta). Annals of Botany 95: 207-217.

Lewis, W., Stripling, H., Ross, R. 1962. Chromosome numbers for some Angiosperms of the Southern United States and Mexico. Rhodora 64: 147-161.

Poggio, L., Bughardt, A., Hunziker, J. 1989. Nuclear DNA variation in diploid and polyploid taxa of Larrea (Zygophyllaceae). Heredity 63: 321-328.

Poggio, L., Hunziker, J. 1986. Nuclear DNA content variation in Bulnesia. Journal of Heredity 77(1): 43-48.

Robertson, K. 1973. The Krameriaceae in the Southeastern United States. Journal of the Arnold Arboretum 54: 322-327.

Simpson, B., SkVArla, J. 1981. Pollen morphology and ultrastructure of Krameria (Krameriaceae): Utility in question of intrafamilial and interfamilial classification. American Journal of Botany 68(2): 277-294.

Simpson, B., Helfgott, D., Weeks, A., Larkin, L. 2004. Species relationships in Krameria (Krameriaceae) based on ITS sequences and morphology: Implications for character utility and biogeography. Systematic Botany 29: 97-108.

Soltis, D., Soltis, P., Chase, M., Mort, M., Albach, D., Zanis, M., Savolainen, V., Hahn, W., Нoot, S., Fay, M., Axtell, M., Swensen, S., Prince, I., Kres, W., Nixon, K., Farris, J. 2000. Angiosperm phylogeny inferred from 18S rDNA, rbcL, and atpB sequences. Botanical Journal of the Linnean Society 133: 381-461.

Squeo, F., Arancio, G., Gutiérrez, J.R. (eds.). 2001. Libro Rojo de la Flora Nativa y de los Sitios Prioritarios para su Conservación: Región de Coquimbo. Ed. Universidad de La Serena, Chile. 372 pp.

Turner, B. 1958. Chromosome numbers in the genus Krameria: evidence for familial status. Rhodora 60: 101-106.

Recibido: 14.01 .2016

Aceptado: 03.10.2016 